\title{
Antioxidant status and risk of cancer in the SU.VI.MAX study: is the effect of supplementation dependent on baseline levels?
}

\author{
Pilar Galan ${ }^{1}$, Serge Briançon ${ }^{2}$, Alain Favier ${ }^{3,4}$, Sandrine Bertrais ${ }^{1}$, Paul Preziosi ${ }^{1}$, Henri Faure ${ }^{4}$, Josiane Arnaud ${ }^{4}$, \\ Nathalie Arnault ${ }^{1}$, Sébastien Czernichow ${ }^{1}$, Louise Mennen ${ }^{1}$ and Serge Hercberg ${ }^{1,5}$ \\ ${ }^{1}$ U557 Inserm (UMR Inserm/Inra/CNAM), Institut Scientifique et Technique de la Nutrition et de l'Alimentation/CNAM, 5 rue Vertbois, \\ F-75003 Paris, France \\ ${ }^{2}$ Ecole de Santé Publique, Epidémiologie clinique, Faculté de Médecine, CHU Nancy EA 3444, France \\ ${ }^{3}$ Laboratoire Lésions des Acides Nucléiques, UMR CNRS-CEA-UJF 5046, Grenoble, France \\ ${ }^{4}$ Département de Biologie Intégrée Bâtiment B - CHU La Tronche BP 217 - 38043 Grenoble Cedex 9, France \\ ${ }^{5}$ Unité de Surveillance et d'Epidémiologie Nutritionnelle (USEN), InVS/CNAM, Paris, France
}

(Received 9 November 2004 - Revised 10 February 2005 - Accepted 14 February 2005)

\begin{abstract}
The SUpplementation en VItamines et Mineraux AntioXydants (SU.VI.MAX) study, a randomised double-blind, primary-prevention trial showed that after $7 \cdot 5$ years, low-dose antioxidant supplementation lowered the total cancer incidence in men, but not in women. To explain this difference in the impact of antioxidant supplementation in men and women, we hypothesised that the effect of supplementation is dependent on initial antioxidant status; 12741 French adults (7713 females aged 35-60 years; 5028 males aged 45-60 years) received daily antioxidant supplementation (120 mg vitamin C, 30 mg vitamin E, $6 \mathrm{mg} \beta$-carotene, $100 \mu \mathrm{g} \mathrm{Se}, 20 \mathrm{mg} \mathrm{Zn}$ daily) or a matching placebo. Cut-off limits for baseline serum concentrations of the different antioxidant vitamins and minerals were defined as follows for both men and women: $0.3 \mu \mathrm{mol} / 1$ for $\beta$-carotene, $11.4 \mu \mathrm{mol} / 1$ for vitamin $\mathrm{C}, 15 \mu \mathrm{mol} / 1 \mathrm{for}$ vitamin $\mathrm{E}, 0.75 \mu \mathrm{mol} / 1$ for Se and $10.7 \mu \mathrm{mol} / 1$ for $\mathrm{Zn}$. The percentage of men with serum concentrations under cut-off limits was higher for vitamins $\mathrm{C}$ and $\mathrm{E}$ and $\beta$-carotene in those who developed a cancer than in those who did not. The risk of cancer was higher in men with baseline concentrations of serum vitamin $\mathrm{C}$ or vitamin $\mathrm{E}$ under cut-off limits, but not in women. The effect of supplementation was greater in men with baseline serum concentrations of vitamin $\mathrm{C}$, vitamin $\mathrm{E}$ and $\beta$-carotene below the cut-off limits compared with those above it. This effect was maintained only for vitamin E after adjustment for age, tobacco, and alcohol consumption and BMI. No effect of supplementation could be seen in women. Baseline antioxidant status is related to the risk of cancer in men but not in women and therefore does not entirely explain the differences observed in the effect of antioxidant supplementation on cancer risk between sexes in the SU.VI.MAX study.
\end{abstract}

Antioxidants: Cancers: Primary-prevention trial: Minerals: Vitamins: Supplementation

The SUpplementation en VItamines et Mineraux AntioXydants (SU.VI.MAX) study, a randomised double-blind, placebo-controlled primary-prevention trial, was designed to test whether a combination of antioxidant nutrients, at nutritional doses (reachable by a healthy diet with high consumption of fruits and vegetables) can reduce the incidence of cancers and ischaemic CVD in a middle-aged general French population (Hercberg et al. 1998b). Intention-to-treat analysis showed that after 7.5 years, low-dose antioxidant supplementation lowered the total cancer incidence in men, but not in women (Hercberg et al. 2004). The same pattern was observed for all-cause mortality. Our results differ from those observed in previous intervention trials on this topic, which have not been able to show a beneficial effect (Physicians' Health Study (Hennekens et al. 1996); Women's Health Study (Lee et al. 1999)) or which even found a deleterious effect (Alpha-Tocopherol, Beta Carotene Cancer
Prevention Study (Anonymous, 1994); Beta Carotene and Retinol Efficacy Trial (Omenn et al. 1996)). However, those trials used pharmacological doses of antioxidant nutrients, mainly alone or in pairs, and included subjects at high cancer risk (heavy smokers and occupationally exposed subjects). Only the Linxian Trial (Blot et al. 1993), which included nutritional doses of a combination of several antioxidant vitamins and minerals, also showed a beneficial effect on total mortality and cancer incidence. Furthermore, in contrast to the Alpha-Tocopherol, Beta Carotene Cancer Prevention Study and the Beta Carotene and Retinol Efficacy Trial, the Linxian trial was conducted in a general Chinese population with very low baseline micronutrient status, due to poor life conditions in this region.

An explanation for some of the differences in the impact of antioxidant supplementation on cancer incidence in all published randomised trials might lie in the differences in pre-inclusion 
antioxidant status of the studied populations. Similarly, the fact that supplementation was effective in men but not in women in the SU.VI.MAX study (Hercberg et al. 2004) may be due to a lower nutritional intake and thus lower baseline concentrations of $\beta$-carotene and vitamin $C$ in men than in women.

We hypothesise that the effect of antioxidant supplementation depends on baseline antioxidant status; only when the baseline status is low, can antioxidant supplementation have a beneficial effect on cancer incidence. We tested this hypothesis in the SU.VI.MAX study using cut-off limits for serum concentrations of vitamins and minerals previously published as corresponding to risk of biological deficiencies without obvious clinical manifestation (Pilch \& Senti, 1985; van Dael \& Deelstra, 1993; Hercberg et al. 1994).

\section{Materials and methods}

\section{Study design}

Details concerning study rationale, design, methods and participant characteristics have been reported elsewhere (Hercberg et al. 1998a,b, 2004). In March-July 1994, information on the objectives and outline of the study was presented in various media types, along with a call for volunteers (women, aged 35-60 years, or men, aged 45-60 years, living in France). Candidates responded by phone or mail. Comprehensive information on the scientific and practical features of the study was sent to those subjects that met the above criteria. They were expected to return a signed informed consent and a completed questionnaire to screen for eligibility. Further eligibility criteria were: lack of disease likely to hinder active participation or threaten 5-year survival, acceptance of the idea of a placebo and of the implications of participation, lack of regular supplementation with any of the tested vitamins or minerals and absence of extreme beliefs or behaviour regarding diet. Finally, the study cohort involved 12741 French adults (7713 females aged 3560 years and 5028 males aged 45-60 years). They were randomly allocated to receive either a combination of antioxidants $(120 \mathrm{mg}$ vitamin C, $30 \mathrm{mg}$ vitamin E, $6 \mathrm{mg} \beta$-carotene (as synthetic forms), $100 \mu \mathrm{g} \mathrm{Se}$ (as Se-enriched yeast) and $20 \mathrm{mg} \mathrm{Zn} \mathrm{(as} \mathrm{gluconate))} \mathrm{or}$ a matching placebo, in a single daily capsule. The study agents were provided in size 1, hard gelatin capsules dispensed in weekly strips. A special box containing fifty-two weekly strips was given to the subjects at the time of the inclusion visit and at each following yearly check-up visit. The median follow-up time was 7.54 years.

The protocol was approved by a medical ethics committee and the national committee for the protection of privacy and civil liberties (Hercberg et al. 1998b).

Data on medical status, alcohol consumption, smoking, etc. were obtained at study entry, along with height and weight. Age was defined in four classes $(<45$ years, $45-50$ years, 50-55 years and $>55$ years, the first class including only women). The classes for smoking were defined as: smokers; former smokers; current smokers. Alcohol consumers were defined as those subjects who reported consuming more than $4 \mathrm{~g}$ ethanol/d in the baseline questionnaire. BMI was calculated as weight $(\mathrm{kg})$ divided by height squared $\left(\mathrm{m}^{2}\right)$ and was divided into three classes $\left(<25,25-30\right.$ and $\left.>30 \mathrm{~kg} / \mathrm{m}^{2}\right)$. Obesity was defined as a BMI $>30 \mathrm{~kg} / \mathrm{m}^{2}$.
Venous blood samples were obtained at inclusion from $12 \mathrm{~h}$ fasting subjects to measure serum cholesterol and antioxidant concentrations in all subjects. All biochemical measurements were performed in only one laboratory for each nutrient being analysed.

Vitamin C status was evaluated using an automated method based on continuous flow analysis (Bourgeois et al. 1989). Serum $\beta$-carotene and $\alpha$-tocopherol were measured by HPLC (Vuilleumier et al. 1983). Serum Zn was determined by flame atomic absorption spectrometry (Arnaud et al. 1986) and serum Se by electrothermal atomic absorption spectrometry with the Zeeman effect (Arnaud et al. 1993). Cut-off limits for serum concentrations of the different antioxidant vitamins and minerals were as follows: $0.3 \mu \mathrm{mol} / \mathrm{l}$ for $\beta$-carotene; $11.4 \mu \mathrm{mol} / \mathrm{l}$ for vita$\min \mathrm{C} ; 15 \mu \mathrm{mol} / \mathrm{l}$ for $\alpha$-tocopherol (vitamin E); $0.75 \mu \mathrm{mol} / \mathrm{l}$ for Se; $10 \cdot 7 \mu \mathrm{mol} / 1$ for Zn (Pilch \& Senti, 1985; val Dael \& Deelstra, 1993; Hercberg et al. 1994).

We had previously reported that randomisation yielded intervention and placebo groups balanced at baseline for factors related to nutritional status and/or cancer risk. For the groups, the mean age was 46.6 (SD 6.6) years for females and 51.3 (SD $4 \cdot 6$ ) years for males. Smoking habits, alcohol consumption, occupation, capsule compliance, BMI, cholesterol, blood levels of $\beta$-carotene, vitamin $C$, vitamin $\mathrm{E}, \mathrm{Zn}$ and Se were identically distributed across the groups (Hercberg et al. 2004). Seventy-four percent of the participants reported at the end of follow-up having taken at least two-thirds of the capsules. There were no differences in capsule consumption between the groups (mean percentage of capsules taken was $79 \%$ in each).

\section{Cancer ascertainment and review}

Participants were asked to complete a monthly questionnaire, summarising treatment compliance and health events, via Minitel (a phone-based French terminal), the Internet or mail. If there was no contact with the participant for a long period, or if the participant failed to appear at the yearly visit, an investigation was launched to determine the reasons. If necessary, an inquiry was made among neighbours and/or the participant's physician. Whatever the source of information, once a cancer was suspected, all relevant records, including results of diagnostic tests and procedures, were collected from the physicians and hospitals involved or directly from participants.

All data were reviewed by an expert committee, whose members were blinded for supplementation assignment. Cancers (ICD10 codes C00-C97 and D00-D09; World Health Organization, 1993) were validated by pathology reports.

Causes of death were confirmed by information from relatives or physicians. At the end of the follow-up, vital status of all subjects and causes of death were checked at the national death registry.

\section{Statistical analysis}

All analyses were stratified by sex. Follow-up duration for each subject was calculated from the date of randomisation until the date of cancer diagnosis or the date of death on 1 September 2002. All cases of cancer were retained for analysis, except for basal cell carcinoma of the skin.

Differences in serum concentrations of antioxidants between sexes were evaluated with the $t$ test, and the relationship between antioxidant status and its determinants (age, smoking, alcohol consumption and BMI) was evaluated using the Fisher test. 
Because of skewed distribution, serum $\beta$-carotene and vitamin $\mathrm{C}$ were log-transformed for analysis to obtain a normal distribution.

To evaluate the relationship between baseline concentrations of antioxidant vitamins and minerals and risk of cancer occurrence, Cox proportional hazard models were used. The same method was applied to assess the effect of antioxidant supplementation on cancer incidence, and these analyses were stratified according to baseline antioxidant status. To evaluate a possible interaction between the antioxidant supplementation group and antioxidant status at baseline, an interaction term (supplementation $\times$ serum concentration) was included in the model (without stratification).

Statistical analyses were performed using SAS software version 8.2 (SAS Institute, Inc., Cary, NC, USA).

\section{Results}

Baseline status of antioxidants in the placebo group and their determinants

At baseline, women had significantly higher baseline serum $\beta$-carotene and vitamin $\mathrm{C}$ concentrations $(P<0 \cdot 0001)$ and lower concentration of serum vitamin $\mathrm{E}, \mathrm{Zn}$ and $\mathrm{Se}(P<0 \cdot 0001)$ than men (Table 1); $36.8 \%$ of men and $15.0 \%$ of women in the placebo group had serum $\beta$-carotene concentrations $<0.30 \mu \mathrm{mol} / \mathrm{l}$; respectively 1.9 and $0.5 \%$ had serum vitamin $\mathrm{C}$ levels $<11.4 \mu \mathrm{mol} / 1 ; 0.6 \%$ of both sexes exhibited serum $\alpha$-tocopherol $<15 \mu \mathrm{mol} / \mathrm{l} ; 4.5$ and $9.5 \%$ had serum $\mathrm{Zn}<10.7 \mu \mathrm{mol} / \mathrm{l}$ and 1.3 and $1.6 \%$ had serum $\mathrm{Se}<0.75 \mu \mathrm{mol} / \mathrm{l}$.

Table 1. Baseline levels and percentage of values under cut-off points in men and women of the placebo group

(Mean values and standard deviations)

\begin{tabular}{|c|c|c|c|c|c|}
\hline & \multicolumn{2}{|c|}{ Men } & \multicolumn{2}{|c|}{ Women } & \multirow[b]{2}{*}{$P$} \\
\hline & Mean & SD & Mean & SD & \\
\hline \multicolumn{6}{|l|}{$\beta$-Carotene } \\
\hline$n$ & \multicolumn{2}{|c|}{2128} & \multicolumn{2}{|c|}{3287} & \\
\hline $\begin{array}{l}\text { Serum concentration } \\
(\mu \mathrm{mol} / \mathrm{l})\end{array}$ & 0.46 & 0.36 & 0.67 & 0.47 & 0.0001 \\
\hline Percentage $<0.30 \mu \mathrm{mol} / /$ & \multicolumn{2}{|c|}{$36 \cdot 8$} & \multicolumn{2}{|c|}{$15 \cdot 0$} & \\
\hline \multicolumn{6}{|l|}{ Vitamin C } \\
\hline$n$ & \multicolumn{2}{|c|}{1836} & \multicolumn{2}{|c|}{2847} & \\
\hline $\begin{array}{l}\text { Serum concentration } \\
(\mu \mathrm{mol} / \mathrm{l})\end{array}$ & $49 \cdot 8$ & $23 \cdot 8$ & $59 \cdot 4$ & $28 \cdot 6$ & 0.0001 \\
\hline Percentage $<11.4 \mu \mathrm{mol} / \mathrm{l}$ & \multicolumn{2}{|c|}{1.9} & \multicolumn{2}{|c|}{0.5} & \\
\hline \multicolumn{6}{|l|}{ Vitamin $\mathrm{E}$} \\
\hline$n$ & \multicolumn{2}{|c|}{2128} & \multicolumn{2}{|c|}{3288} & \\
\hline $\begin{array}{l}\text { Serum concentration } \\
(\mu \mathrm{mol} / \mathrm{l})\end{array}$ & $32 \cdot 2$ & $8 \cdot 2$ & $30 \cdot 9$ & $7 \cdot 5$ & 0.0001 \\
\hline Percentage $<15.0 \mu \mathrm{mol} / \mathrm{l}$ & \multicolumn{2}{|c|}{0.6} & \multicolumn{2}{|c|}{0.6} & \\
\hline \multicolumn{6}{|l|}{$\mathrm{Zn}$} \\
\hline$n$ & \multicolumn{2}{|c|}{2404} & \multicolumn{2}{|c|}{3664} & \\
\hline $\begin{array}{l}\text { Serum concentration } \\
(\mu \mathrm{mol} / \mathrm{l})\end{array}$ & 13.5 & 1.9 & $12 \cdot 9$ & $1 \cdot 8$ & 0.0001 \\
\hline Percentage $<10.7 \mu \mathrm{mol} / \mathrm{l}$ & \multicolumn{2}{|c|}{4.5} & \multicolumn{2}{|c|}{9.5} & \\
\hline \multicolumn{6}{|l|}{$\mathrm{Se}$} \\
\hline$n$ & \multicolumn{2}{|c|}{2395} & \multicolumn{2}{|c|}{3643} & \\
\hline $\begin{array}{l}\text { Serum concentration } \\
(\mu \mathrm{mol} / \mathrm{l})\end{array}$ & $1 \cdot 13$ & 0.20 & 1.08 & 0.19 & 0.0001 \\
\hline Percentage $<0.75 \mu \mathrm{mol} / \mathrm{l}$ & \multicolumn{2}{|c|}{$1 \cdot 3$} & \multicolumn{2}{|c|}{$1 \cdot 6$} & \\
\hline
\end{tabular}

A higher percentage of women with concentration of serum $\beta$-carotene under the cut-off limit $(P<0.03)$ was observed at a younger age (Table 2). The prevalence of subjects with antioxidant concentrations under the cut-off limit was higher in current smokers than in non-smokers for $\beta$-carotene $(P<0 \cdot 0001)$, vitamin $\mathrm{C}(P<0.0001$ in men; $P<0.03$ in women $)$ and $\mathrm{Se}(P<0.001$ in men; $P<0.007$ in women). In alcohol consumers, low values were more frequently observed for serum $\beta$-carotene $(P<0.0001$ in men; $P<0.03$ in women), whereas for vitamin $\mathrm{E}$, the prevalence of low values was lower $(P<0.0004)$ among men consumers. The percentage of subjects with serum $\beta$-carotene under cut-off limits was much higher in obese than in overweight or normal-to-low-weight subjects $(P<0.0001$ with a significant linear relationship in both sexes).

\section{Risk of cancer according to baseline status of antioxidants in the placebo group}

In the placebo group, mean baseline serum $\beta$-carotene and vitamin $\mathrm{C}$ concentrations were lower in men who developed a cancer than in those who did not (Table 3). No significant difference was found for serum vitamin $\mathrm{E}, \mathrm{Zn}$ or Se. Baseline status of the five antioxidant markers was not related to cancer in women. The percentages of men with serum concentrations under the cutoff limits were higher in those who developed a cancer when compared with those who did not for vitamin $\mathrm{C}$, vitamin $\mathrm{E}$ and $\beta$-carotene (Table 3).

Relative risks for cancer according to baseline serum antioxidants concentrations below or above cut-off limits in the placebo group are presented in Table 4 .

In men, a low serum $\beta$-carotene, serum vitamin $C$ or vitamin $E$ concentration was positively associated with the risk of cancer. Adjustment for age, smoking, alcohol consumption and BMI did not modify the relationship for vitamin $\mathrm{E}$; however, the relationship with $\beta$-carotene and vitamin $\mathrm{C}$ disappeared after adjustment. No association was observed in women.

\section{Effect of supplementation on risk of cancer according to baseline cut-off}

In men, we found a significant interaction between antioxidant supplementation and baseline serum vitamin $\mathrm{C}$ concentration (significant for interaction term in the model; $P=0.04$; Table 5 ). No such interaction was observed for $\beta$-carotene $(P=0 \cdot 20)$, vitamin $\mathrm{E}$ $(P=0.55), \mathrm{Zn}(P=0.90)$ or Se $(P=0.97)$, nor were there any interactions in women.

In men, the effect of supplementation was stronger in those with low serum vitamin $\mathrm{C}$ concentrations than in those with higher concentration; relative risk for cancer in the supplemented group of men with serum levels of vitamin $\mathrm{C}<11.4 \mu \mathrm{mol} / \mathrm{l}$ was 0.10 (95\% CI 0.01, 0.77; $P<0.03$ ) and 0.83 (95\% CI 0.60, 1.16; $P=0.28)$ in those with serum levels of vitamin $\mathrm{C} \geq 11.4 \mu \mathrm{mol} / \mathrm{l}$ when compared with the placebo.

The relative risk of developing a cancer in the supplemented group of men with serum concentrations of $\beta$-carotene $<0.3 \mu \mathrm{mol} / 1$ was 0.59 (95\% CI $0.37,0.95 ; P<0.03)$ v. 0.88 (95\% CI $0.61,1.28 ; P=0.50)$ in the group with initial concentrations of serum $\beta$-carotene $>0 \cdot 3 \mu \mathrm{mol} / \mathrm{l}$. For vitamin $\mathrm{E}$, the relative risks in men with serum levels below or above the cut-off limits of $15 \mu \mathrm{mol} / 1$ were respectively 0.39 (95\% CI 0.04, 3.83; $P=0.42)$ and 0.76 (95\% CI $0.57,1.02 ; P=0.07)$. 
Table 2. Percentage of subjects with baseline serum vitamin and mineral concentrations below cut-off limits in men and women according to age, tobacco and alcohol consumption and BMI

\begin{tabular}{|c|c|c|c|c|c|c|c|c|c|c|}
\hline & \multicolumn{2}{|c|}{$\begin{array}{l}\text { Serum } \beta \text {-carotene } \\
\quad<0.30 \mu \mathrm{mol} / \mathrm{l}\end{array}$} & \multicolumn{2}{|c|}{$\begin{array}{l}\text { Serum vitamin C } \\
\quad<11.4 \mu \mathrm{mol} / /\end{array}$} & \multicolumn{2}{|c|}{$\begin{array}{l}\text { Serum vitamin } E \\
\quad<15 \mu \mathrm{mol} / /\end{array}$} & \multicolumn{2}{|c|}{$\begin{array}{l}\text { Serum Zn } \\
<10.7 \mu \mathrm{mol} / /\end{array}$} & \multicolumn{2}{|c|}{$\begin{array}{l}\text { Serum Se } \\
<0.75 \mu \mathrm{mol} / \mathrm{l}\end{array}$} \\
\hline & Men & Women & Men & Women & Men & Women & Men & Women & Men & Women \\
\hline \multicolumn{11}{|l|}{ Age } \\
\hline$<45$ years & - & $16 \cdot 7$ & - & 0.5 & - & 0.8 & - & $9 \cdot 0$ & - & $2 \cdot 2$ \\
\hline $45-50$ years & $34 \cdot 1$ & $15 \cdot 9$ & $1 \cdot 2$ & 0.4 & 0.9 & 0.7 & 3.9 & $8 \cdot 8$ & 0.8 & 1.5 \\
\hline $50-55$ years & $39 \cdot 7$ & $12 \cdot 4$ & 2.5 & 0.8 & 0.3 & 0.5 & $4 \cdot 8$ & $10 \cdot 3$ & $1 \cdot 8$ & 0.9 \\
\hline$>55$ years & $37 \cdot 2$ & $12 \cdot 5$ & $2 \cdot 0$ & 0.6 & 0.6 & 0.4 & $5 \cdot 1$ & $10 \cdot 9$ & 1.6 & $1 \cdot 3$ \\
\hline$P$ & 0.09 & 0.03 & 0.25 & 0.76 & 0.42 & 0.76 & 0.45 & 0.42 & 0.14 & 0.17 \\
\hline \multicolumn{11}{|l|}{ Tobacco } \\
\hline Non-smokers & $26 \cdot 9$ & $12 \cdot 7$ & $1 \cdot 1$ & 0.3 & 0.4 & 0.5 & $3 \cdot 6$ & $9 \cdot 7$ & 0.7 & $1 \cdot 2$ \\
\hline Former smokers & $38 \cdot 8$ & $13 \cdot 7$ & 1.4 & 0.5 & 0.5 & $1 \cdot 0$ & $4 \cdot 8$ & $9 \cdot 8$ & $1 \cdot 1$ & $1 \cdot 7$ \\
\hline Current smokers & $51 \cdot 4$ & 24.5 & $5 \cdot 5$ & 1.4 & $1 \cdot 2$ & 0.6 & $5 \cdot 9$ & 7.9 & 3.4 & $3 \cdot 2$ \\
\hline$P$ & 0.0001 & 0.0001 & 0.0001 & 0.03 & 0.25 & 0.30 & 0.20 & 0.37 & 0.001 & 0.007 \\
\hline \multicolumn{11}{|l|}{ Alcohol consumption } \\
\hline Non-drinkers & $26 \cdot 9$ & $12 \cdot 5$ & $1 \cdot 2$ & 0.8 & $1 \cdot 3$ & 0.8 & $3 \cdot 7$ & 9.0 & $1 \cdot 2$ & $1 \cdot 8$ \\
\hline Drinkers & $39 \cdot 1$ & $16 \cdot 4$ & $2 \cdot 0$ & 0.3 & 0.4 & 0.7 & $4 \cdot 6$ & 9.5 & 1.4 & 1.6 \\
\hline$P$ & 0.0001 & 0.003 & 0.36 & 0.12 & 0.04 & 0.75 & 0.44 & 0.53 & 0.74 & 0.56 \\
\hline \multicolumn{11}{|l|}{ BMI $\left(\mathrm{kg} / \mathrm{m}^{2}\right)$} \\
\hline$<25$ & $25 \cdot 1$ & $11 \cdot 1$ & 1.5 & 0.4 & 0.7 & 0.7 & 3.9 & $10 \cdot 1$ & 1.6 & 1.6 \\
\hline $25-30$ & $39 \cdot 3$ & $15 \cdot 7$ & 0.9 & 0.5 & 0.4 & 0.2 & $5 \cdot 6$ & 8.7 & $1 \cdot 3$ & $2 \cdot 0$ \\
\hline$>30$ & 63.0 & 31.5 & $3 \cdot 2$ & 0.7 & 0.7 & 0.6 & $3 \cdot 1$ & $6 \cdot 6$ & 0.6 & $1 \cdot 7$ \\
\hline$P$ & 0.0001 & 0.0001 & 0.14 & 0.87 & 0.81 & 0.50 & 0.16 & 0.22 & 0.61 & 0.81 \\
\hline
\end{tabular}

For $\mathrm{Zn}$, the relative risk of developing cancer in the supplemented group of men with serum levels $\geq 10.7 \mu \mathrm{mol} / \mathrm{l}$ was $0.74(95 \%$ CI $0.55,0.98 ; P=0.034) v .0 .81$ for those $<$ $10.7 \mu \mathrm{mol} / 1$ (95\% CI $0.24,2.80 ; P=0.74)$. For Se, the relative risk of developing a cancer in the supplemented group of men with serum levels $\geq 0.75 \mu \mathrm{mol} / 1$ was 0.73 (95\% CI 0.55 , $0.97 ; P=0.027)$ v. 0.84 (95\% CI $0.05,13.45 ; P=0.90)$,

No difference in the effect of supplementation according to baseline levels was shown in women.

\section{Discussion}

The present study revealed lower concentrations of $\beta$-carotene and vitamin $\mathrm{C}$ at baseline in men than in women, which is in line with the hypothesis that the difference in the effect of antioxidant supplementation that we observed between men and women is dependent on baseline antioxidant status. This observation is consistent with the results of numerous studies performed in different countries with subjects in the same age range (Hercberg et al.

Table 3. Baseline vitamin and mineral status in men and women, and subjects who developed or did not develop a cancer in the placebo group

(Mean values and standard deviations)

\begin{tabular}{|c|c|c|c|c|c|c|c|c|c|c|}
\hline & \multicolumn{5}{|c|}{ Men } & \multicolumn{5}{|c|}{ Women } \\
\hline & \multicolumn{2}{|c|}{ Cancer } & \multicolumn{2}{|c|}{ No cancer } & \multirow[b]{2}{*}{$P$} & \multicolumn{2}{|c|}{ Cancer } & \multicolumn{2}{|c|}{ No cancer } & \multirow[b]{2}{*}{$P$} \\
\hline & Mean & SD & Mean & SD & & Mean & SD & Mean & SD & \\
\hline \multicolumn{11}{|l|}{$\beta$-Carotene } \\
\hline$n$ & \multicolumn{2}{|c|}{104} & \multicolumn{2}{|c|}{2024} & & \multicolumn{2}{|c|}{134} & \multicolumn{2}{|c|}{3153} & \\
\hline Serum concentration $(\mu \mathrm{mol} / \mathrm{l})$ & 0.42 & 0.34 & 0.47 & 0.36 & 0.03 & 0.67 & 0.47 & 0.64 & 0.45 & 0.87 \\
\hline Percentage $<0.30 \mu \mathrm{mol} / \mathrm{l}$ & \multicolumn{2}{|c|}{$45 \cdot 2$} & \multicolumn{2}{|c|}{36.3} & 0.07 & \multicolumn{2}{|c|}{11.2} & \multicolumn{2}{|c|}{$15 \cdot 2$} & 0.20 \\
\hline \multicolumn{11}{|l|}{ Vitamin C } \\
\hline$n$ & \multicolumn{2}{|c|}{86} & \multicolumn{2}{|c|}{1750} & & \multicolumn{2}{|c|}{124} & \multicolumn{2}{|c|}{2723} & \\
\hline Serum concentration $(\mu \mathrm{mol} / \mathrm{l})$ & $45 \cdot 2$ & $21 \cdot 7$ & $50 \cdot 0$ & 23.9 & 0.003 & 55.9 & $19 \cdot 5$ & $59 \cdot 5$ & 28.9 & 0.16 \\
\hline Percentage $<11.4 \mu \mathrm{mol} / \mathrm{l}$ & \multicolumn{2}{|c|}{$9 \cdot 3$} & \multicolumn{2}{|c|}{1.5} & 0.0001 & \multicolumn{2}{|c|}{1.6} & \multicolumn{2}{|c|}{0.5} & 0.09 \\
\hline \multicolumn{11}{|l|}{ Vitamin E } \\
\hline$n$ & \multicolumn{2}{|c|}{104} & \multicolumn{2}{|c|}{2024} & & \multicolumn{2}{|c|}{134} & \multicolumn{2}{|c|}{3154} & \\
\hline Serum concentration $(\mu \mathrm{mol} / \mathrm{l})$ & 31.5 & $7 \cdot 8$ & $32 \cdot 2$ & $8 \cdot 2$ & 0.39 & $30 \cdot 8$ & 6.5 & 30.9 & 7.6 & 0.88 \\
\hline Percentage $<15.0 \mu \mathrm{mol} / \mathrm{l}$ & \multicolumn{2}{|c|}{2.9} & & & 0.002 & & & & & 0.87 \\
\hline $\mathrm{Zn}$ & & & & & & & & & & \\
\hline$n$ & & & & & & & & & & \\
\hline Serum concentration $(\mu \mathrm{mol} / \mathrm{l})$ & $13 \cdot 6$ & 1.9 & 13.5 & 1.8 & 0.57 & $12 \cdot 8$ & $2 \cdot 1$ & $12 \cdot 9$ & 1.0 & 0.57 \\
\hline Percentage $<10.7 \mu \mathrm{mol} / \mathrm{l}$ & & & & & 0.91 & & & & & 0.20 \\
\hline $\mathrm{Se}$ & & & & & & & & & & \\
\hline$n$ & & & & & & & & & & \\
\hline Serum concentration $(\mu \mathrm{mol} / \mathrm{l})$ & $1 \cdot 14$ & 0.21 & $1 \cdot 13$ & 0.19 & 0.62 & 1.08 & 0.16 & 1.08 & 0.20 & 0.68 \\
\hline Percentage $<0.75 \mu \mathrm{mol} / \mathrm{l}$ & & & & & 0.64 & & & & & 0.30 \\
\hline
\end{tabular}


1994; Olmedilla et al. 1994, 2002; Curran-Celentano et al. 2001; De Waart et al. 2001; Wallström et al. 2001). Differences in nutritional intake (especially fruit and vegetable consumption) may explain the difference in status of these vitamins and carotenoids. It is possible that hormonal factors or lifestyle factors (alcohol consumption, smoking habits, etc.) also contribute to this difference.

The percentage of subjects with high risk of biological deficiency is generally low, except for $\beta$-carotene. These percentages, as well as the serum concentrations, are in agreement with previous studies conducted in France and other European countries (Millet et al. 1989; Hercberg et al. 1994; Carbajal et al. 1996; Benton et al. 1997).

In the placebo group, baseline serum concentrations of vitamin $\mathrm{C}$, vitamin $\mathrm{E}$ and $\beta$-carotene were significantly lower in men who developed cancer than in the control group, but not in women. Furthermore, we observed a trend toward higher cancer incidence among men with low baseline serum concentration of vitamin $C$, vitamin $\mathrm{E}$ and $\beta$-carotene, but this relationship was confounded for $\beta$-carotene and vitamin $\mathrm{C}$ by other risk factors, and did not remain after adjustment. We observed a similar tendency in women for vitamins $\mathrm{C}$ and $\mathrm{E}$, but no statistically significant relationship was found. It should be noted that the number of women with serum concentrations under the cut-off limits was very small.

Prospective analysis in the placebo group suggested a protective effect against cancer for men with baseline serum concentrations of vitamin $C, \beta$-carotene and vitamin $E$ above the cut-off. Numerous prospective studies have been published showing an inverse association between blood concentrations of $\beta$-carotene (Nomura et al. 1985; Wald et al. 1988; Connett et al. 1989; Comstock et al. 1991; Orentreich et al. 1991; Stähelin et al. 1991; van Poppel \& Goldbohm, 1995), vitamin C (Hsing et al. 1990, Eischholzer et al. 1996) and vitamin E (Knekt, 1988; Knekt et al. 1988a,b; Hsing et al. 1990; Comstock et al. 1991; Stähelin et al. 1991) and the incidence of cancer or cancer mortality. Such an association appears most consistent for lung and stomach cancers, whereas the association seems inconsistent for breast and prostate cancer. The lack of relationship with breast cancer may explain why we did not find any relationship in women. Indeed, in the present study, breast cancer represented the main cancer site in females; 195 out of 350 total cancers after 7.5 years of follow-up (Hercberg et al. 2004). Results of studies relating blood concentrations of vitamin $\mathrm{E}$ are less consistent. Most prospective studies on blood markers of antioxidants and cancers involved only male populations. In few prospective studies performed on both sexes, plasma ascorbic acid was inversely related to cancer mortality in men, but not in women (Enstrom et al. 1992; Loria et al. 2000; Khaw et al. 2001).

Several strengths of the present study should be mentioned. First, we had the opportunity to prospectively assess the association with baseline antioxidant levels and cancer incidence in a large sample of subjects. However, one concern is that our subjects were enrolled in a nutritional intervention study. Although a previous report on baseline characteristics of participants in the SU.VI.MAX study showed that the study sample was close to the national population with regard to geographic density and socio-economic status, these subjects may have a healthier lifestyle (Hercberg et al. 1998b). Second, in the present study we used cut-off limits rather than percentiles to assess the risk of developing cancer. These cut-off limits do not correspond to major deficiency (with clinical signs), but are usually considered to define a risk of moderate deficiency with impaired biological functions. In our analysis these cut-off limits seem 
Table 5. Relative risk (RR) of cancer according to baseline serum antioxidant concentrations (below or over cut-off limits) in supplemented group compared with placebo, and interactions between sex and serum baseline level

(RR and $95 \% \mathrm{Cl}$ )

\begin{tabular}{|c|c|c|c|c|c|c|}
\hline & \multicolumn{3}{|c|}{ Men } & \multicolumn{3}{|c|}{ Women } \\
\hline & $\mathrm{RR}$ & $95 \% \mathrm{Cl}$ & $P$ & $\mathrm{RR}$ & $95 \% \mathrm{Cl}$ & $P$ \\
\hline \multicolumn{7}{|l|}{ Serum $\beta$-carotene } \\
\hline$<0.30 \mu \mathrm{mol} / \mathrm{l}$ & 0.59 & $0.37,0.95$ & 0.0285 & $1 \cdot 15$ & $0.58,2 \cdot 28$ & 0.6941 \\
\hline$\geq 0.30 \mu \mathrm{mol} / \mathrm{l}$ & 0.88 & $0.61,1.28$ & 0.4965 & $1 \cdot 18$ & $0.92,1.51$ & 0.1918 \\
\hline Interaction & & & 0.20 & & & 0.95 \\
\hline \multicolumn{7}{|l|}{ Serum vitamin $C$} \\
\hline$<11.4 \mu \mathrm{mol} / \mathrm{l}$ & $0 \cdot 10$ & $0.01,0.77$ & 0.0271 & 0.55 & $0.05,6.09$ & 0.6274 \\
\hline$\geq 11.4 \mu \mathrm{mol} / \mathrm{l}$ & 0.83 & $0.60,1.16$ & 0.2776 & 1.09 & $0.86,1.40$ & 0.4778 \\
\hline Interaction & & & 0.04 & & & 0.58 \\
\hline \multicolumn{7}{|l|}{ Serum vitamin $E$} \\
\hline$<15.03 \mu \mathrm{mol} / \mathrm{l}$ & 0.39 & $0.04,3.83$ & 0.4219 & 0.38 & $0.01,15.29$ & 0.6058 \\
\hline$\geq 15.03 \mu \mathrm{mol} / \mathrm{l}$ & 0.76 & $0.57,1.02$ & 0.0706 & $1 \cdot 17$ & $0.93,1.47$ & 0.1863 \\
\hline Interaction & & & 0.55 & & & 0.97 \\
\hline \multicolumn{7}{|l|}{ Serum Se } \\
\hline$<0.75 \mu \mathrm{mol} / \mathrm{l}$ & 0.84 & $0.05,13.45$ & 0.8987 & 3.09 & $0.32,29.67$ & 0.3291 \\
\hline$\geq 0.75 \mu \mathrm{mol} / \mathrm{l}$ & 0.73 & $0.55,0.97$ & 0.0270 & 1.06 & $0.86,1.32$ & 0.5738 \\
\hline Interaction & & & 0.97 & & & 0.35 \\
\hline \multicolumn{7}{|l|}{ Serum Zn } \\
\hline$<10.7 \mu \mathrm{mol} / \mathrm{l}$ & 0.81 & $0 \cdot 24,2 \cdot 80$ & 0.7416 & 0.97 & $0.53,1.77$ & 0.9142 \\
\hline$\geq 10.7 \mu \mathrm{mol} / \mathrm{l}$ & 0.74 & $0.55,0.98$ & 0.0349 & 1.08 & $0.86,1.36$ & 0.5195 \\
\hline Interaction & & & 0.90 & & & 0.74 \\
\hline
\end{tabular}

appropriate for categorising subjects with higher risk of cancers, suggesting a threshold effect.

These cut-off limits were also good predictors of the effects of antioxidant supplementation. The reduction in the risk of cancer in the supplemented group of men with serum levels of vitamin $\mathrm{C}, \mathrm{E}$ or $\beta$-carotene below cut-off limits was much higher than the risk reduction observed in the supplemented group when the population was studied independently of the initial baseline status or in subjects with concentration above cut-off limits (Hercberg et al. 2004).

In women, a tendency toward reduction in risk in subjects with serum vitamin levels below cut-off limits for vitamin $\mathrm{C}$ and $\mathrm{E}$ was found, but the number of subjects with cancer in this group was too low for statistical power. The more favourable status in women compared with men for vitamin $\mathrm{C}$ and $\beta$-carotene at inclusion, and the too-small number of cancers, mainly breast cancers, may explain why, unlike men, we were unable to find a specific relationship between these biomarkers and the risk of cancers in the placebo group, nor a specific effect of supplementation according to the initial level of the antioxidant.

For $\mathrm{Zn}$ and $\mathrm{Se}$, a decrease in the risk of cancer in the supplemented group was seen only in men with serum values above the cut-off limit concentrations. This supplementation does not seem to affect men with low values, and no relationship was observed in women.

The baseline level of antioxidants may be an important factor for explaining discrepancies between intervention trials on this topic, which involved different populations. The only study which found protective effects of antioxidant supplementation on cancer (the Linxian trial), included a population with a very low baseline micronutrient status, due to poor living conditions (Blot et al. 1993). As baseline mean levels of antioxidants suggest, it is likely that many subjects presented very low levels, which was not the case in the other studies not demonstrating a protective effect (Anonymous, 1994; Hennekens et al. 1996; Omenn et al. 1996; Lee et al. 1999).
These observations agree with the present results as we found no beneficial effects in females who had higher concentrations of serum antioxidants at baseline than males; in addition, in males the beneficial effect of supplementation was more pronounced in vitamin- and $\beta$-carotene-sub-deficient subjects. The differences in cancer risk according to supplementation and basal antioxidant status in men may be related to the fact that we corrected biological deficiencies important enough to increase the risk of cancer. In subjects with adequate status (above the cutoff limits), supplementation was not useful. However, we do not have a clear explanation as to why baseline antioxidant status is related to the risk of cancer in men but not in women. It could be related to the type of cancer observed in women (mainly breast cancers), the higher serum values of vitamin $\mathrm{C}$ and $\mathrm{E}$ in women with too-small a number of women with biochemical evidence of deficiency. The difference in baseline antioxidant status does not totally explain the differences observed in the effect of antioxidant supplementation on cancer risk between sexes in the SU.VI.MAX study. Therefore, further investigation should be undertaken in the future.

\section{Acknowledgements}

We are grateful to the staff of the SU.VI.MAX study, all the teams who assisted in the fieldwork of the study and to the dedicated and conscientious volunteers who participated in this trial.

We thank the International Scientific Committee which supervised study progress: Professor Elio Riboli (President), Centre International de Recherche sur le Cancer, IARC/WHO, Lyon; Mr Pierre Ducimétière, U258 INSERM, Paris; Professor William Dab, Conservatoire National des Arts et Métiers, Paris; Professor JeanFrançois Desjeux, U290 INSERM/Chaire de Biologie, CNAM, Paris; Professor Marcel Goldberg, U88 INSERM, St Maurice; Professor Joseph Hautvast, Wageningen Centre for Food Sciences, 
Wageningen, The Netherlands; Dr Michel Chauliac, Direction Générale de la Santé, Ministère de la Santé, Paris; Professor François Meyer, Centre de Recherche, Hôpital St Sacrement, Québec, Canada; Professor Jean Neve, Faculté de Pharmacie, Bruxelles, Belgium; Professor Fernando Viteri, Department of Nutritional Science, University of California, Berkeley, CA, USA.

We thank all the scientists who were members of the validating committees for cancers: Professor T. Conroy; Dr A Ledoux; Dr Parache (Centre Alexis Vautrin, Nancy); Dr Marie-Christine Boutron (Inserm).

We wish to acknowledge all scientists who helped to carry out the SU.VI.MAX study.

The SU.VI.M.AX project received grant support from public and private sectors. Special acknowledgements are addressed to UBF, Fruit d'Or Recherche, Lipton, Cereal, Candia, Kellogg's, CERIN, LU/Danone, Sodexho, L'Oréal, Estée Lauder, Peugeot, Jet Service, RP Scherer, France Telecom, Becton Dickinson, Fould Springer, Boehringer Diagnostic, Seppic Givaudan Lavirotte, Air Liquide, Carboxyque, Klocke, Trophy Radio, Jouan, Perkin Elmer.

S. H. was the principal investigator. S. H., P. G., P. P., A. F. and S. B. designed the study. H. F. and J. A. guaranteed the quality of analyses. P. G., P. P., S. H. and S. B. collected the data. S. B., P. P., P. G., S. H., S. B., L. M. and N. A. carried out data analysis. P. G., S. H., L. M. and S. B. prepared the manuscript, which was reviewed by all authors. P. G. is the guarantor.

There are no competing interests.

\section{References}

Anonymous (1994) The effect of vitamin E and beta carotene on the incidence of lung cancer and other cancers in male smokers. The AlphaTocopherol, Beta Carotene Cancer Prevention Study Group. N Eng J Med 330, 1029-1035.

Arnaud J, Bellanger J, Bienvenu F, Chappuis P \& Favier A (1986) Méthode recommandée de dosage du zinc sérique par absorption atomique en flamme (Recommended method for assaying serum zinc with flame atomic absorption). Ann Biol Clin 44, 77-87.

Arnaud J, Prual A, Preziosi P, Favier A \& Hercberg S (1993) Selenium determination in human milk in Niger: influence of maternal status. J Trace Elem Electrolytes Health Dis 7, 199-204.

Benton D, Haller J \& Fordy J (1997) The vitamin status of young British adults. Int $J$ Vit Nutr Res 67, 34-40.

Blot WJ, Li JY, Taylor PR, et al. (1993) Nutrition intervention trials in Linxian, China: supplementation with specific vitamin/mineral combinations, cancer incidence, and disease-specific mortality in the general population. J Natl Cancer Inst 85, 1483-1492.

Bourgeois CF, Chartois RR, Counstans MF \& George PR (1989) Automated determination of vitamin $\mathrm{C}$ in foodstuffs and biological tissues. Analysis 9, 519-525.

Carbajal A, Nunez C \& Moreiras O (1996) Energy intake as a determinant factor of vitamin status in healthy young women. Int J Vit Nutr Res 66, $227-231$.

Comstock GW, Helzsouer KJ \& Bush TL (1991) Prediagnostic serum levels of carotenoids and vitamin $\mathrm{E}$ as related to subsequent cancer in Washington County, Maryland. Am J Clin Nutr 53, Suppl., 260S-264S

Connett JE, Kuller LH, Kjelsberg MO, Polk BF \& Rider A (1989) Relationship between carotenoids and cancer. The multiple risk factor intervention trial (MRFIT) study. Cancer 64, 126-134.

Curran-Celentano J, Hammond BR, Ciulla TA, Cooper DA, Pratt LM \& Danis RB (2001) Relation between dietary intake, serum concentrations, and retinal concentrations of luthein and zeaxanthin in adults in Midwest population. Am J Clin Nutr 74, 796-802.
De Waart FG, Schouten EG, Stalenhoef AFH \& Kok FJ (2001) Serum carotenoids, $\alpha$-tocopherol and mortality risk in a prospective study among Dutch elderly. Int J Epidemiol 30, 136-143.

Eischholzer M, Stahelin HB, Gey KF, Ludin E \& Bernasconi F (1996) Prediction of male cancer mortality by plasma levels of interacting vitamins: 17-year follow-up of the prospective Basel study. Int J Cancer 66, $145-150$

Enstrom JE, Kanim LE \& Klein MA (1992) Vitamin C intake and mortality among a sample of the United States population. Epidemiology 3, 194-202.

Hennekens CH, Buring JE, Manson JE, et al. (1996) Lack of effect of long-term supplementation with beta-carotene on the incidence of malignant neoplasms and cardiovascular disease. N Eng J Med 334, 1145-1149.

Hercberg S, Galan P, Preziosi P, Bertrais S, Mennen L, Malvy D, Roussel AM, Favier A \& Briançon S (2004) The SU.VI.MAX study: a randomised, placebo-controlled trial of the health effects of antioxidant vitamins and minerals. Arch Intern Med 164, 1-8.

Hercberg S, Galan P, Preziosi P, Roussel AM, Arnaud J, Richard MJ, Malvy D, Paul-Dauphin A, Briancon S \& Favier A (1998a) Background and rationale behind the SU.VI.MAX Study, a prevention trial using nutritional doses of a combination of antioxidant vitamins and minerals to reduce cardiovascular diseases and cancers. Int $J$ Vit Nutr Res 68, 3-20.

Hercberg S, Preziosi P, Briançon S, Galan P, Triol I, Malvy D, Roussel AM \& Favier A (1998b) A primary-prevention trial of nutritional doses of antioxidant vitamins and minerals on cardiovascular diseases and cancers in general population: The SU.VI.MAX Study. Design, methods and participant characteristics. Control Clin Trials 19, 336-351.

Hercberg S, Preziosi P, Galan P, Devanlay M, Keller H, Bourgeois C, Potier de Courcy G \& Cherouvrier F (1994) Vitamin status of a healthy French population: dietary intakes and biochemical markers. Int $J$ Vit Nutr Res 64, 220-232.

Hsing AW, Comstock GW, Abbey H \& Polk BF (1990) Serologic precursors of cancer. Retinol, carotenoids, and tocopherol and risk of prostate cancer. J Natl Cancer Inst 82, 941-946.

Khaw KT, Bingham S, Welch A, Luben R, Wareham N, Oakes S \& Day N (2001) Relation between plasma ascorbic acid and mortality in men and women in EPIC-Norfolk prospective study: a prospective population study. Lancet 357, 657-663.

Knekt P (1988) Serum vitamin E level and risk of female cancers. Int J Epidemiol 17, 281-286.

Knekt P, Aromaa A, Maatela J, et al. (1988a) Serum vitamin E and risk of cancer among Finnish men during a 10-year follow-up. Am J Epidemiol 127, 28-33.

Knekt P, Aromaa A, Maatela J, Alfthan G, Aaran RK, Teppo L \& Hakama M (1988b) Serum vitamin E, serum selenium and the risk of gastrointestinal cancer. Int J Cancer 42, 846-850.

Lee IM, Cook NR, Manson JE, Buring JE \& Hennekens CH (1999) Betacarotene supplementation and incidence of cancer and cardiovascular disease: The Women's Health Study. J Natl Cancer Inst 24, 2102-2106.

Loria CM, Klag MJ, Caulfield LE \& Whelton PK (2000) Vitamin C status and mortality in US adults. Am J Clin Nutr 72, 139-145.

Millet P, Guilland JC, Fuchs F \& Klepping J (1989) Nutrient intake and vitamin status of healthy French vegetarians and non vegetarians. Am J Clin Nutr 50, 718-727.

Nomura AMY, Stemmermann GN, Heilbrun LK, Salkeld RM \& Vuilleumier JP (1985) Serum vitamin levels and the risk of cancer of specific sites in men of Japanese ancestry in Hawaii. Cancer Res $\mathbf{4 5}$, 2369-2372.

Olmedilla B, Granado F, Blanco I \& Rojas-Hidalgo E (1994) Seasonal and sex-related variations in six serum carotenoids, retinol, and alpha-tocopherol. Am J Clin Nutr 60, 106-110.

Olmedilla B, Granado F, Southon S, et al. (2002) A European multicentre, placebo-controlled supplementation study with $\alpha$-tocopherol, carotene- 
rich palm oil, lutein or lycopene: analysis of serum responses. Clin Sci 102, 447-456.

Omenn GS, Goodman GE, Thornquist MD, et al. (1996) Effects of a combination of beta-carotene and vitamin $\mathrm{A}$ on lung cancer and cardiovascular disease. $N$ Eng $J$ Med 334, 1150-1155.

Orentreich N, Matias JR, Vogelman JH \& Salked RM (1991) The predictive value of serum $\beta$-carotene for subsequent development of lung cancer. Nutr Cancer 15, 167-168.

Pilch SM \& Senti FR (1985) Analysis of zinc data from the second National Health and Nutrition Examination Survey (NHANES II). J Nutr 115, 1393-1397.

Stähelin HB, Gey KF, Eichlolzer M, Ludin E, Bernasconi F, Thurneysen J \& Brubacher G (1991) Plasma antioxidant vitamins and subsequent cancer mortality in the 12-year follow-up of the prospective Basel study. Am J Epidemiol 133, 766-775.

van Dael P \& Deelstra H (1993) Selenium. Int J Vit Nutr Res 63, 312-316. van Poppel G \& Goldbohm RA (1995) Epidemiologic evidence for $\beta$-carotene and cancer prevention. Am J Clin Nutr 62, Suppl., 1393S-1402S.

Vuilleumier JP, Keller HE, Gysel D \& Hunziker F (1983) Clinical chemical methods for the routine assessment of the vitamin status in human population. Part I: the fat-soluble vitamins $\mathrm{A}$ and $\mathrm{E}$ and beta-carotene. Int J Vitam Nutr Res 53, 265-272.

Wald NJ, Thompson SG, Densem JW, Boreham J \& Bailey A (1988) Serum $\beta$-carotene and subsequent risk of cancer: results from the BUPA study. Br J Cancer 57, 428-433.

Wallström P, Wirfalt E, Lahmann PH, Gullberg B, Janzon L \& Berglund G (2001) Serum concentration of $\beta$-carotene and $\alpha$-tocopherol are associated with diet, smoking, and general and central adiposity. Am J Clin Nutr 73, 777-785.

World Health Organization (1993) Classification Statistique Internationale des Maladies et des Problèmes de Santé Connexes, 10th revisionvol. 1, Geneva: WHO. 